\title{
Impor gandum Indonesia dan faktor-faktor yang Mempengaruhinya
}

\author{
Gita Wulandari*; Siti Hodijah; Yohanes Vyn Amzar
}

Prodi. Ekonomi Pembangunan, Fak. Ekonomi dan Bisnis,Universitas Jambi

*E-mail korespondensi: gitawulandari458@gmail.com

\begin{abstract}
This study aims: 1) to analyze the development of wheat import volume, gross domestic product (GDP), inflation, investment credit interest rates, and population of Indonesian wheat imports. 2) to analyze the effect of gross domestic product, inflation, investment interest rates on Indonesian wheat imports. This study is a descriptive study and the types of data used in this study are secondary data in the form of gross domestic product, inflation, investment credit interest rates, and population for the last 18 years (2000-2017). The data obtained were processed using SPSS 20 with multiple linear regression models using the Ordinary Least Square (OLS) method. The results of this study indicate that the gross domestic product (GDP) obtained a significant level of 0.03 , inflation obtained a significant level of 0.598, and the total population obtained a significant level of 0.522. The regression results show that partially only the variable gross domestic product (GDP) and interest rates are Investment credit interest has a significant effect on imports of Indonesian wheat, while inflation and population have no significant effect on imports of Indonesian wheat.
\end{abstract}

Keywords: GDP, Inflation, Interest rates, Population

\begin{abstract}
Abstrak
Penelitian ini bertujuan: 1) untuk menganalisis perkembangan volume impor gandum, produk domestik bruto (PDB), inflasi, suku bunga kredit investasi dan jumlah penduduk terhadap impor gandum Indonesia. 2) untuk menganalisis pengaruh produk domestik bruto, inflasi, suku bunga investasi terhadap impor gandum Indonesia. Penelitian ini merupakan penelitian deksriptif dan jenis data yang digunakan dalam penelitian ini yaitu data sekunder berupa produk domestic bruto, inflasi, suku bunga kredit investasi dan jumlah penduduk dengan rentang waktu 18 tahun terakhir (2000-2017). Data yang diperoleh diolah menggunakan SPSS 20 dengan model regresi linier berganda metode Ordinary Least Square (OLS). Hasil penelitian ini menunjukan bahwa produk domestik bruto (PDB) diperoleh tingkat signifikan sebesar 0,03, Inflasi diperoleh tingkat signifikan sebesar 0,598, dan jumlah penduduk diperoleh tingkat signifikan sebesar 0,522 hasil regresi menunjukan bahwa secara parsial hanya variabel produk domestik bruto (PDB) dan suku bunga kredit investasi berpengaruh signifikan terhadap impor gandum Indonesia, Sedangkan variabel inflasi dan jumlah penduduk tidak berpengaruh signifikan terhadap impor gandum Indonesia.
\end{abstract}

Kata kunci: PDB, Inflasi, Suku bunga, Jumlah penduduk

\section{PENDAHULUAN}

Indonesia merupakan negara yang kaya akan sumber daya alam baik sumber daya alam nabati maupun sumber daya alam mineral yang tersebar luas di wilayah 
Indonesia. Indonesia juga merupakan negara agraris yang sebagian besar penduduknya masih bermata pencarian sebagai petani. Sektor pertanian sampai saat ini masih memegang peranan penting bagi perekonomian nasional dan merupakan sektor yang mendasari kehidupan setiap masyarakat di Indonesia. Indonesia juga merupakan negara dengan jumlah penduduk yang besar. Dari tahun ke tahun jumlah penduduk di Indonesia terus mengalami pertumbuhan. Dengan jumlah penduduk yang besar tersebut, konsumsi akan kebutuhan pokok seperti sandang dan pangan juga besar. Tanaman ini tumbuh baik di daerah beriklim sub tropis, jadi tidak heran jika di Indonesia jarang di temuin tanaman gandum ini.

Gandum merupakan komoditas pangan yang terbanyak diproduksi di dunia dibanding jagung dan padi, bahkan jumlah produksinya dari tahun ke tahun semangkin meningkat. Dengan tingkat pertumbuhan produksi rata-rata 2-3\% pertahun, gandum menjadi tanaman utama di dunia. Permintaan akan gandum tidak terlepas dari banyaknya derivasi produk yang bisa dihasilkan dari gandum. Jika diolah menjadi tepung, turunan gandum ini dapat digunakan untuk membuat berbagai olahan makanan. Dari segi modernitas pangan, gandum lebih unggul dari tanaman serelia lain seperti jagung dan padi, gandum merupakan salah satu tanaman serelia yang menjadi sumber kalori. Maka pertimbangan yang dilakukan pemerintah pada zaman itu memperkenalkan tepung gandum sebagai salah satu pangan alternatif kebutuhanpokok Indonesia divertisifikasi makanan, saat bersamaan harga gandum yang relatif stabil dan volume yang di perdagangan cukup banyak. Sehingga beras pada saat itu bersubtitusi dengan tepung terigu, konsumsi pangan berbasis tepung terigu semakin berkembang di Indonesia. Dampakdari perubahan pola konsumsi dari masyarakat antara lain adalah meingkatnya permintaan terhadap produk olahan gandum. Gandum sesungguhnya bukanlah makanan pokok penduduk Indonesia namun selama beberapa tahun terakhir perannya sangat penting bagi kelangsungan hidup Penduduk Indonesia. Dibawah ini menunjukan angka pertumbuhan Volume Impor Gandum Indonesia tahun 2000 sampai dengan 2017.

Tabel 1. Data perkembangan volume impor gandum Indonesia

\begin{tabular}{ccc}
\hline Tahun & Volume Impor gandum Ribu (Ton) & Persentase (\%) \\
\hline 2013 & 82.073 & - \\
2014 & 7.253 & 0.74 \\
2015 & 7.857 & 8.33 \\
2016 & 8.130 & 3.47 \\
2017 & 8.351 & 2.72 \\
\hline Rata-rata & $\mathbf{7 . 7 5 8}$ & $\mathbf{3 . 0 5}$ \\
\hline
\end{tabular}

Sumber: Diolah, Badan Pusat Statistik,2018

Pada Tabel 1 dapat dilihat perkembangan volume impor gandum Indonesia tahun 2000-2017, memiliki rata-rata perkembangan sebesar -1,45 persen pertahun yang selalu mengalami fluktuasi permintaan impor. Pada tahun 2000, volume impor gandum Indonesia mencapai 459.064 ribu ton, pada tahun 2001 impor gandum mengalami penurunan volume impor yang cukup dratis dari tahun sebelumnya, hal ini di sebabkan 
penurunan produksi gandum di negara pendalaman . Hal ini di karenakan kondisi kering lahan gandum akibat cerah hujan dibawah rata-rata terjadi di wilayah tersebut. Berdasarkan Tabel 5.1dapat dilihat bahwa rata-rata perkembangan sebesar $\mathbf{- 7 . 5 8}$ persen. Perkembangan tertinggi tercatat pada tahun 2005 yaitu sebesar 50.49persen, sedangkan perkembangan mengalami penurunan tercatat penurunan terendah 2003 yaitu sebesar -0.07 persen.

Perkembangan volume impor gandum tertinggi terjadi pada tahun 2005 yaitu mencapai 50,49 persen dari tahun sebelumnya dengan volume impor gandum sebesar 477.976 ribu ton, hal ini dikarenakan kenaikan permintaan impor gandum yang dilakukan produsen tepung terigu dalam negeri dan kenaikan impor tersebut disebabkan oleh kebutuhan konsumsi yang terus meningkat. Selain itu, industry produk hilir tepung terigu seperti biskuit dan makanan ringan juga terus berkembang.Pada tahun 2008, perkembangan volume impor gandum terjadi penurunan dari tahun ke tahun sebelumnya yang terus mengalami peningkatan volume impor gandum sebesar 530.918 ribu ton, ini disebabkan oleh sejumlah produsen pengolah tepung terigu lokal mengalami penurunan produksi akibat permintaan produk olahan gandum melemah. Perkembangan volume impor gandum mengalami penurunan terendah pada tahun 2017 yaitu mencapai 2,72 persen dari tahun sebelumnya, faktor utama terjadinya penurunan volume impor gandum pada tahun ini dikarenakan kebijakan pemerintah Indonesia diberlakukanya bea masuk tarif impor gandum sebesar 20 persen pada tahun tersebut dan industri gandum dalam negeri sudah banyak berkembang.

\section{METODE}

Metode yang digunakan dalam penelitian ini merupakan metode deskriptif kuantitatif dan jenis data yang digunakan adalah data sekunder yang berbentuk data tahunan (time series). Data yang digunakan dalam penelitian ini bersumber dari Badan Pusat Statistik (BPS) dan Bank Indonesia (BI).Dilakukan analisis kuantitatif dengan menggunakan analisis regresilinier berganda.Regresi linier berganda digunakan untuk melihat sejauh mana pengaruh variabel $\mathrm{X}$ (independent variabel) terhadap variabel $\mathrm{Y}$ (dependent variabel) serta melakukan pengujian terhadap hipotesis yang diajukan, dimana variabel (X) yang digunakan adalah PDB (X1), inflasi (X2), suku bunga kredit investasi (X3), dan jumlah penduduk(X4), sedangkan variabel (Y) yang digunakan dalam penelitian ini adalah impor gandum, dengan model ekonometrika sebagai yang digunakan pada penelitian ini adalah analisis regresi berganda sebagai berikut: (Gunawan, 2007)

$$
Y_{t}=\beta_{0}+\beta_{1} X_{1 t}+\beta_{2} X_{2 t}+\beta_{3} X_{3 t}+\beta_{4} X_{4 t}
$$

Dimana :

$\begin{array}{ll}\mathrm{Y}_{\mathrm{t}} & =\text { Volume impor gandum Indonesia } \\ \mathrm{X}_{1 \mathrm{t}} & =\text { Produk domestik bruto } \\ \mathrm{X}_{2 \mathrm{t}} & =\text { Inflasi } \\ \mathrm{X}_{3 \mathrm{t}} & =\text { Suku bunga kredit investasi } \\ \mathrm{X}_{4 \mathrm{t}} & =\text { Jumlah penduduk } \\ \beta_{0} & =\text { Intersep } \\ \beta_{1} \beta_{2} \text { dan } \beta_{3} & =\text { Koefisien regresi } \\ \mathrm{t} & =\text { Time series (periode waktu penelitian 2000-2017) } \\ \varepsilon \mathrm{t} & =\text { Error term }\end{array}$




\section{HASIL DAN PEMBAHASAN}

Perkembangan volume impor gandum, PDB, inflasi, suku bunga kredit, investasi dan jumlah penduduk.

Untuk menjawab pertanyaan dari rumusan masalah yang pertama dalam penelitian ini, maka penulis mencoba menguraikan perkembangan dari masing-masing variabel dalam penelitian selama periode penelitian yakni dari tahun 2000 sampai dengan tahun 2017.

Awal mulanya gandum Indonesia terjadi pada masa orde baru, kebijkan pemerintah yang mempertahankan harga relatif rendah berdampak kepada masyarakat meningkatnya konsumsi beras. Sehingga harga beras tidak stabil dan stok beras dalam negeri terbatas, pada saat itu juga Indonesia kesulitan devisa dan volume beras yang diperdagangan didunia menipis. Maka pertimbangan yang dilakukan pemerintah pada zaman itu memperkenalkan tepung gandum sebagai salah satu pangan alternatif kebutuhan pokok Indonesia. Disisi lain kemampuan Indonesia memproduksi gandum dalam negeri yang masih rendah mengharuskan permerintah untuk melakukan impor gandum untuk memenuhi kebutuhan pangan gandum dalam negeri. Secara keseluruhan dari tahun 2000 sampai tahun 2017 volume impor gandum Indonesia mengalami pertumbuhan yang semakin meningkat dari tahun ke tahun seperti pada tabel berikut:

Tabel 2. Perkembangan Produk Domestik Bruto (PDB) Tahun 2000-2017

\begin{tabular}{ccc}
\hline Tahun & $\begin{array}{c}\text { PDB harga konstan 2010 } \\
\text { (Miliar Dollar) }\end{array}$ & Persentase (\%) \\
\hline 2013 & 897.3 & - \\
2014 & 942.2 & 5.00 \\
2015 & 988.1 & 4.87 \\
2016 & 1037.7 & 5.02 \\
2017 & 1090,3 & 5.07 \\
\hline Rata-rata & $\mathbf{7 . 7 5 8}$ & 5.004 \\
\hline
\end{tabular}

Sumber: Diolah, Badan Pusat Statistik,2018

Berdasarkan Tabel 5.2 dapat dilihat bahwa rata-rata perkembangan sebesar 5.004 persen. Perkembangan tertinggi tercatat pada tahun 2007 yaitu sebesar 6.36 persen, sedangkan perkembangan mengalami penurunan tercatat penurunan terendah 2001 yaitu sebesar 3.64 persen.

Tabel 3. Perkembangan inflasi Tahun 2000-2017

\begin{tabular}{cc}
\hline Tahun & Inflasi (\%) \\
\hline 2013 & - \\
2014 & 8.36 \\
2015 & 3.35 \\
2016 & 3.02 \\
2017 & 3.61 \\
\hline Rata-rata & $\mathbf{7 . 1 9}$
\end{tabular}

Sumber: Diolah, Badan Pusat Statistik,2018 
Berdasarkan Tabel 3 dapat dilihat perkembangan rata-rata inflasi, tahunan umum Indonesia selama 18 tahun sebesar 7.19 persen per tahun mengacu periode 2000-2017 dimana perkembangan inflasi terjadi secara naik turun atau berfluktuasi. Perkembangan tertinggi tercatat pada tahun 2001 yaitu sebesar 12.55 persen, sedangkan perkembangan mengalami penurunan tercatat penurunan terendah pada tahun 2009 yaitu sebesar 2.78 persen.

Tabel 4. Perkembangan suku bunga kredit investasi Tahun 2000-2017

\begin{tabular}{cc} 
Tahun & Suku bunga kredit investasi $(\%)$ \\
\hline 2013 & - \\
2014 & 12,36 \\
2015 & 12,12 \\
2016 & 11,21 \\
2017 & 12,38 \\
\hline Rata-rata & 13.9 \\
\hline
\end{tabular}

Sumber: Diolah, Badan Pusat Statistik,2018

Berdasarkan Tabel 4 dapat dilihat bahwa suku bunga kredit investasi cenderung mengalami penurunan setiap tahunnya. Rata-rata perkembangan suku bunga kredit investasi sebesar 13.9 persen, perkembangan suku bunga kredit investasi yang tertinggi tercatat pada tahun 2001 yaitu sebesar 17,90 persen, sedangkan perkembangan mengalami penurunan tercatat penurunan terendah 2016 yaitu 11,21 persen.

Tabel 5. Jumlah penduduk Tahun 2000-2017

\begin{tabular}{ccc}
\hline Tahun & $\begin{array}{c}\text { Jumlah Penduduk } \\
\text { (Ribu Jiwa) }\end{array}$ & Persentase (\%) \\
\hline 2013 & 252.032 .263 & - \\
2014 & 255.131 .116 & 1.23 \\
2015 & 258.162 .113 & 1.19 \\
2016 & 261.115 .456 & 1.14 \\
2017 & 263.991 .379 & 1.10 \\
\hline Rata-rata & $\mathbf{7 . 7 5 8}$ & 1.31 \\
\hline
\end{tabular}

Sumber: Diolah, Badan Pusat Statistik,2018

Berdasarkan Tabel 5 dapat dilihat bahwa jumlah penduduk Indonesia setiap tahunnya mengalami peningkatan. Rata-rata perkembangan jumlah penduduk di Indonesia selama tahun 2000-2017 sebesar 1,31 persen. Perkembangan tertinggi tercatat pada tahun 2003 yaitu sebesar 1.40 persen. Tingginya perkembangan jumlah penduduk tahun 2003 karena diiringi dengan tinggi angka kelahiran pada tahun yang sama. Sedangkan perkembangan terendah tercatat pada tahun 2017 yaitu sebesar 1,10 persen. 


\section{Pengujian asumsi klasik}

\section{Normalitas data}

Uji normalitas dapat dilihat pada grafik Normal P-Plot Gambar 1. Pada grafik PPlot terlihat data menyebar di sekitar garis diagonal dan mengikuti arah garis histograf menuju pola distribusi normal maka variabel dependen Y memenuhi asumsi normalitas.

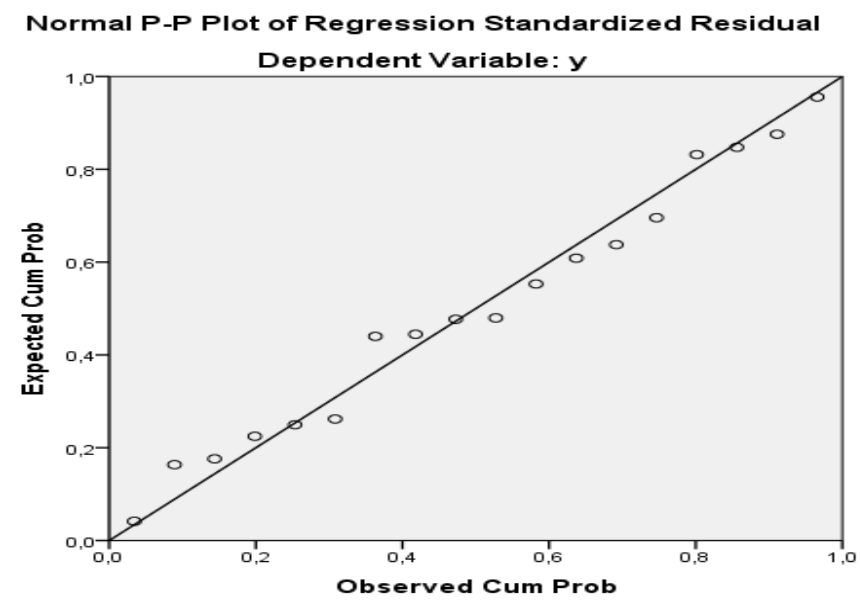

Gambar 1. Uji normalitas

\section{Uji multikolinieritas}

Multikolinieritas berarti adanya hubungan yang kuat diantara beberapa atau semua variabel bebas pada model regresi. Jika terdapat multikolinieritas maka koefisien regresi menjadi tak tentu, tingkat kesalahannya menjadi sangat besar dan biasanya ditandai dengan koefisien determinasi yang sangat besar tetapi pada pengujian parsial koefisien regresi, tidak ada ataupun kalau ada sangat sedikit sekali koefisien regresi yang signifikan. Pada penelitian ini digunakan nilai variance inflantion factors (VIF) sebagai ada tidaknya multikolinieritas diantara variabel bebas.

Tabel 6. Hasil pengujian asumsi multikolinieritas

\begin{tabular}{clcc}
\hline No & \multicolumn{1}{c}{ Variabel } & Tollerance & VIF \\
\hline 1. & PDB &, 246 & 4,068 \\
2. & Inflasi &, 320 & 3,123 \\
3. & Suku Bunga Kredit Investasi &, 205 & 4,878 \\
4. & Jumlah Penduduk &, 522 & 1,914 \\
\hline Rata-rata & $\mathbf{7 . 7 5 8}$ & 1.31 & \\
\hline
\end{tabular}

Sumber: Diolah, Badan Pusat Statistik,2018

Berdasarkan nilai VIF yang diperoleh pada masing variabel seperti terlihat pada tabel 5.2 menunjukkan nilai VIF dari seluruh variabel bebas lebih kecil dari 10 sehingga dapat disimpulkan tidak terdapat multikolinieritas diantara variabel bebas.

\section{Uji autokorelasi}

Autokorelasi didefinisikan sebagai korelasi/keterkaitan antara serangkaian observasi yang diurutkan menurut waktu dan ruang. Untuk mengetahui adaatau 
tidaknya gejala autokorelasi dalam perhitungan regresi atas penelitianini maka digunakan Durbin-Watson Test sebesar 0,871. Dengan menggunakan tabel statistik d dan derajat kepercayaan $95 \%(\alpha=0,05)$ jumlah observasi 18 serta jumlah variabel bebas 4 maka diperoleh angka $\mathrm{dl}=0,574$ dan $\mathrm{du}=1,631$ sedangkan nilai untuk $4-\mathrm{dl}=$ 3,426 dan 4-du $=2$,369dengan menggunakan uji statistik Durbin Watson dua ujung (two tailed) maka patokan yang digunakan adalah sebagai berikut :

$\mathrm{d}<\mathrm{dl}=$ berarti terdapat autokorelasi positif

$\mathrm{d}>\mathrm{dU}=$ berarti tidak terdapat autokorelasi positif

$(4-d)<$ dl $=$ berarti terdapat autokorelasi negativ

(4-d) $>\mathrm{dU}=$ berarti tidak terdapat autokorelasi negative

Hasil yang diperoleh adalah nilai DW observasi terletak pada daerah (4-d) $>$ dU atau terdapat autokorelasi negatif dalam penelitian ini.

\section{Uji heteroskedastisitas}

Mendeteksi heteroskedastisitas dapat dilakukan dengan gambar grafik nilai-nilai residu, uji Breusch-Godfrey dan Uji Park.Penelitian ini menggunakan uji BreuschGodfrey.

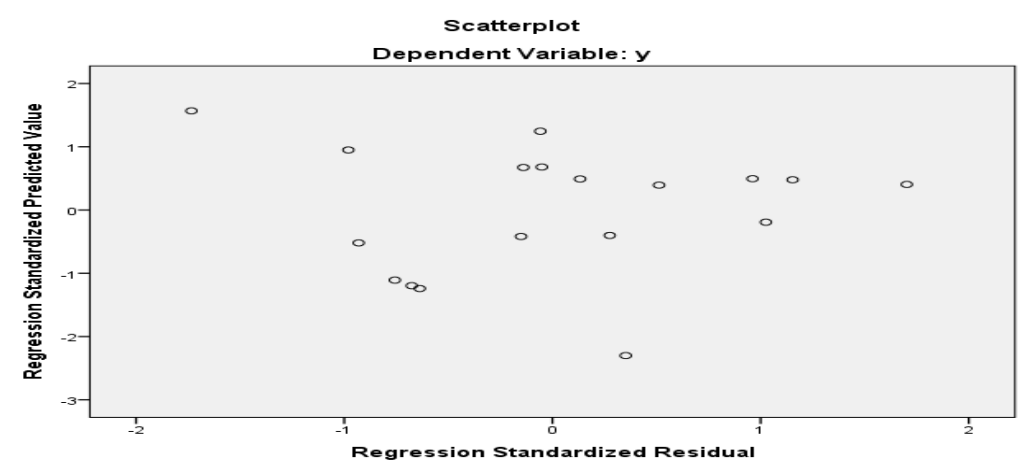

Gambar 5. Uji heteroskedastisitas

Dengan melihat Gambar 5. diketahui bahwa tidak ada pola yang jelas serta titiktitik menyebar diatas dan dibawah 0 dan Sumbu Y. Maka dapat disimpukan tidak terjadi heteroskedastisitas pada model.

\section{Interpretasi hasil regresi linier berganda}

Berdasarkan analisisdiperoleh hasil regresi berganda seperti terangkum pada Tabel 7 berikut:

Tabel 7 Regresi linier berganda

\begin{tabular}{|c|c|c|c|c|c|c|c|}
\hline \multirow{2}{*}{ Model } & \multicolumn{2}{|c|}{ Unstandardized Coefficient } & \multirow{2}{*}{$\begin{array}{c}\begin{array}{c}\text { Standardized } \\
\text { Coefficient }\end{array} \\
\text { Beta }\end{array}$} & \multirow[t]{2}{*}{$\mathbf{t}$} & \multirow{2}{*}{ Sig } & \multicolumn{2}{|c|}{$\begin{array}{c}\text { Colinearity } \\
\text { Statistics }\end{array}$} \\
\hline & B & Std.Eror & & & & Tolerance & VIF \\
\hline Constant & 2966899,60 & 987857,652 & & 3,003 & ,010 & & \\
\hline X1 & $-1741,84$ & 472,467 & $-1,414$ & $-3,687$ & ,003 & 246 & 4,068 \\
\hline $\mathrm{X} 2$ & $-12026,73$ & 22263,030 &,- 182 &,- 540 & 598 &, 320 & 3,12 \\
\hline $\mathrm{X3}$ & $-105782,33$ & 49511,746 &,- 898 & $-2,137$ & 052 & ,205 & 4,878 \\
\hline X4 & 847 & 1,288 & ,173 & ,658 & 522 &, 522 & 1,914 \\
\hline
\end{tabular}

a. Dependent Variable: y

Sumber: Data diolah, 2020 
Berdasarkan Tabel 7 diperoleh persamaan regresi berganda sebagai berikut:

$$
Y_{t}=2.966 .899,599-1.741,844 X_{1 t}-12.026,731 X_{2 t}-105.782,329 X_{3 t}+0,847 X_{4 t}
$$

Persamaan regresi tersebut mempunyai makna sebagai berikut:

Nilai koefisiennya konstanta sebesar 2.966.899,599, artinya jika PDB, inflasi, suku bunga kredit investasi dan jumlah penduduk tidak mengalami perubahan atau tetap, maka impor gandum di Indonesia selama periode 2000-2017 sebesar $2.966 .899,599$ ton.

\section{Koefisien PDB = -1.741,844}

Nilai koefisien PDB sebesar $-1.741,844$, artinya bila terjadi peningkatan PDB sebesar 1 persen maka impor gandum di Indonesia mengalami penurunan sebesar $1.741,844$ ton.

\section{Koefisien Inflasi $=\mathbf{- 1 2 . 0 2 6 , 7 3 1}$}

Nilai koefisien Inflasi sebesar -12.026,731, artinya bila terjadi peningkatan inflasi sebesar 1 persen maka impor gandum di Indonesia mengalami penurunan sebesar $12.026,731$ ton.

\section{Koefisien Suku Bunga Kredit Investasi sebesar = -105.782,329}

Nilai koefisien Suku Bunga Kredit Investasi sebesar -105.782,329, artinya bila terjadi peningkatan suku bunga kredit investasi sebesar 1 persen maka impor gandum di Indonesia mengalami penurunan sebesar -105.782,329 ton.

Koefisien Jumlah Penduduk sebesar $=0,847$. Nilai koefisien Jumlah Penduduk sebesar 0,847 , artinya bila terjadi peningkatan jumlah penduduk Indonesia sebesar 1 persen maka impor gandum di Indonesia mengalami peningkatan sebesar 0,847 ton.

\section{Pengujian hipotesis}

\section{Uji F}

Uji $\mathrm{F}$ digunakan untuk untuk mengetahui apakah variabel-variabel independent secara bersama-sama berpengaruh terhadap variabel dependent. Pengujian dilakukan dengan menggunakan signifikansi level $0,1(\alpha=5 \%)$. Untuk menguji pengaruh antara variabel bebas (variabel independent) yaitu Kurs, Pertumbuhan ekonomi dan Tenaga kerja sektor pertambangan terhadap variabel terikat (variabel dependent) yaitu nilai ekspor gas secara simultan digunakan alat uji $\mathrm{F}$ statistik yang dapat dilihat pada hasil output program SPSS 20 pada tabel ANNOVA sebagai berikut :

Tabel 8. Hasil uji F statistik

\begin{tabular}{llrrrr}
\hline \multicolumn{1}{c}{ Model } & Sum of Squares & \multicolumn{1}{c}{ Df } & Mean Square & \multicolumn{1}{c}{ F } & \multicolumn{1}{c}{ Sig } \\
\hline Regression & 577967426627,191 & 4 & 144491856656,79 & 3,661 &, $003^{\mathrm{b}}$ \\
Residual & 513033569615,253 & 13 & 39464120739,635 &,- 540 & \\
Total & 1091000996242,444 & 17 &,- 898 & $-2,137$ & \\
\hline
\end{tabular}

a. Dependent Variable: y

b. Predictors: (Constant), $\mathrm{X}_{4}, \mathrm{X}_{3}, \mathrm{X}_{2}, \mathrm{X}_{1}$

Sumber: Data diolah, 2020 
Berdasarkan hasil regresi diketahui atau diperoleh signifikansi F-sig sebesar 0,03 lebih kecil dari 0,1. Artinya Ho ditolak dan Ha diterima, hal ini dapat diartikan bahwa variabel bebas (Produk Domestik Bruto, Inflasi, Suku Bunga Kredit Investasi dan Jumlah Penduduk) secara bersama-sama (simultan) berpengaruh signifikan terhadap variabel terikat (Impor Gandum Indonesia) di Indonesia selama periode 2000-2017.

\section{Uji t}

Uji statistik merupakan pengujian secara parsial yang bertujuan untuk mengetahui apakah masing-masing koefisien regresi signifikan atau tidak terhadap variabel dependent dengan menganggap variabel lainnya konstan. Untuk melihat hasil setiap variabel terikat secara parsial yang diuji dengan uji-t secara rinci koefisien regresi pada setiap variabel dapat dilihat pada tabel 5.2 yang menunjukkan hasil sebagai berikut

\section{Variabel $\mathrm{X}_{1}$ (produk domestik bruto)}

Dari hasil pengujian diperoleh nilai probabilita untuk variabel produk domestik bruto sebesar 0,001. Dengan tingkat keyakinan $(\alpha=5 \%)$, dari perhitungan tersebut dapat dilihat bahwa nilai probabilitalebih kecil dari alpha $(0,003<0,1)$, artinya Ho ditolak dan Ha diterima artinya produk domestik bruto berpengaruh signifikan terhadap Impor Gandum Indonesia.

\section{Variabel $\mathbf{X}_{2}$ (inflasi)}

Dari hasil pengujian diperoleh nilai probabilita untuk variabel inflasi sebesar 0,598 . Dengan tingkat keyakinan $(\alpha=5 \%)$, dari perhitungan tersebut dapat dilihat bahwa nilai probabilitalebih besar dari alpha $(0,598>0,1)$, artinya Ho diterima dan Ha ditolak artinya inflasi tidak berpengaruh signifikan terhadap Impor Gandum Indonesia.

\section{Variabel $\mathrm{X}_{3}$ (suku bunga kredit investasi)}

Dari hasil pengujian diperoleh nilai probabilita untuk variabel suku bunga kredit investasi sebesar 0,052. Dengan tingkat keyakinan $(\alpha=5 \%)$, dari perhitungan tersebut dapat dilihat bahwa nilai probabilitalebih kecil dari alpha $(0,052<0,1)$, artinya Ho ditolak dan $\mathrm{Ha}$ diterima artinya suku bunga kredit investasi berpengaruh signifikan terhadap Impor Gandum Indonesia.

\section{Variabel $\mathrm{X}_{4}$ (jumlah penduduk)}

Dari hasil pengujian diperoleh nilai probabilita untuk variabel jumlah penduduk sebesar 0,522. Dengan tingkat keyakinan $(\alpha=5 \%)$, dari perhitungan tersebut dapat dilihat bahwa nilai probabilita lebih besar dari alpha $(0,522>0,1)$, artinya Ho diterima dan Ha ditolak artinya jumlah penduduk tidak berpengaruh signifikan terhadap Impor Gandum Indonesia.

\section{Koefesien determinasi $\left(\mathbf{R}^{2)}\right.$}

Analisis koefisiensi determinasi (KD) digunakan untuk melihat beberapa besarvariabel bebas berpengaruh terhadap variabel terikat yang dinyatakan dalam persentase. Seperti yang ditunjukkan pada tabel berikut:

Tabel 9. Hasil $\mathrm{R}^{2}$ square

\begin{tabular}{|c|c|c|c|}
\hline Model & $\mathbf{R}$ & $\begin{array}{l}\text { Adjusted R } \\
\text { Square }\end{array}$ & $\begin{array}{c}\text { Std. Error of the } \\
\text { Estimate }\end{array}$ \\
\hline 1 &, $728^{\mathrm{a}}$ & ,385 & 198655,78456 \\
\hline
\end{tabular}

Sumber: Data diolah, 2020 
Tabel 9 dapat dilihat model summary diketahui nilai $\mathrm{R}$ sebesar 0,728 . Artinya sebesar 72,8 persen variasi Impor Gandum Indonesia dijelaskan oleh variabel bebas dalam model, sedangkan sisanya 27,2 persen dijelaskan oleh variabel lain diluar penelitian.

\section{Implikasi hasil penelitian}

Berdasarkan hasil analisis penelitian tentang impor gandum Indonesia \& faktorfaktor yang mempengarauhinya. Variabel bebas PDB, inflasi, suku bunga kredit investasi dan jumlah penduduk secara bersama-sama mempengaruhi variabel dependen volume impor gandum sebesar 53 persen dan sisanya dipengaruhi oleh variabel lain yaitu sebesar 47 persen.

\section{Pengaruh produk domestik bruto terhadap impor gandum Indonesia}

Berdasarkan hasil regresi diketahui bahwa produk domestik bruto berpengaruh signifikan dan negatif terhadap impor gandum Indonesia, dengan nilai koefisien sebesar $-1.741,844$, artinya bila terjadi peningkatan produk domestik bruto sebesar 1 milyar dollar AS maka impor gandum Indonesia mengalami penurunan sebesar -1.741,844 ribu ton. Pengaruh negatif tersebut diduga disebabkan peningkatan PDB Indonesia diiringi dengan peningkatan produksi gandum. Hasil penelitian tidak sejalan dengan penelitian yang dilakukan oleh Pradeksa (2014) yang menyimpulkan bahwa PDB berpengaruh positif terhadap impor.

\section{Pengaruh inflasi terhadap impor gandum Indonesia}

Berdasarkan hasil regresi diketahui bahwa inflasi tidak berpengaruh secara signifikan terhadap impor gandum, dengan nilai koefisien sebesar -12.026,731, hal ini menunjukkan tidak terdapat pengaruh yang signifikan antara variabel inflasi dengan impor gandum. Nilai koefisiennya adalah negatif yang artinya bila terjadi peningkatan inflasi sebesar 1 persen maka impor gandum mengalami penurunan sebesar 12.026,731. Hasil penelitian tidak sejalan dengan teori yang dikemukakan oleh Sukirno (2004) yang menyimpulkan bahwa inflasi tidak berpengaruh negatif terhadap impor.

\section{Pengaruh suku bunga kredit investasi terhadap impor gandum Indonesia}

Berdasarkan hasil regresi diketahui bahwa suku bunga kredit investasi berpengaruh signifikan dan negatif terhadap impor gandum Indonesia, dengan nilai koefisien sebesar -105.782,329, artinya bila terjadi peningkatan suku bunga kredit investasi sebesar 1 persen maka impor gandum Indonesia mengalami penurunan sebesar -105.782,329. Pengaruh negatif tersebut diduga disebabkan suku bunga kredit investasi cenderung mengalami penurunan setiap tahunnya. Hasil penelitian tidak sejalan dengan teori yang dikemukakan oleh Mankiw (2006) yang menyimpulkan bahwa suku bunga kredit investasi berpengaruh positifterhadap impor.

\section{Pengaruh jumlah penduduk terhadap impor gandum Indonesia}

Berdasarkan hasil regresi diketahui bahwa jumlah penduduk tidak berpengaruh secara signifikan terhadap impor gandum, dengan nilai koefisien sebesar 0,847 , hal ini menunjukkan tidak terdapat pengaruh yang signifikan antara variabel jumah penduduk dengan impor gandum.Nilai koefisiennya adalah positif yang artinya bila terjadi peningkatan jumlah penduduk sebesar 1000 jiwa maka impor gandum mengalami 
peningkatan sebesar 0,847 persen.Hasil penelitian ini tidak sependapat dengan teori yang dikemukakan oleh Malthus (1999) yang menyimpulkan bahwa jumlah penduduk tidak berpengaruh negatif terhadap impor.

\section{KESIMPULAN DAN SARAN}

\section{Kesimpulan}

Selama tahun 2000-2017, perkembang volume impor gandum rata-rata sebesar 7.58 persen, PDB rata-rata sebesar 5.004 persen, inflasi rata-rata sebesar 10.04 persen, suku bunga kreditinvestasi rata-rata sebesar 13.9 persen, jumlah penduduk rata-rata sebesar 1.31 persen.

Berdasarkan hasil regresi, bahwa variabel PDB dan suku bunga kredit investasi berpengaruhsignifikan terhadap volume impor gandum Indonesia pada alpha 5 persen.

\section{Saran}

Produksi impor gandum hendaknya dapat dimaksimalkan, dengan memaksimalkan lahan yang lebih produktif, bibit unggul dan teknologi yang lebih modern dalam memproduksi gandum agar memberi dampak positif dan mampu bersaing di pasar luar negeri .

Dengan mengetahui variabel-variabel yang mempengaruhi impor gandum Indonesia diharapkan pemerintah instansi terkait mampu menjaga mempertahankan pasar perdangangan luar negeri yang telah ada dengan cara selalu menjaga hubungan perdagangan luar negeri ke Indonesia. Selain itu perlu adanya kerja sama antara pemerintah dengan pengusaha atau instansi terkait mempromosikan gandum di pasar luar negeri serta perlunya dukungan kebijakan pemerintah yang dapat saling menguntungkan terhadap pihak-pihak terkait dalam industri gandum.

\section{DAFTAR PUSTAKA}

Amir M.S. (1999). Ekonomi impor (teori dan penerapannya), PT. Pustaka Bisnaman Presindo: Jakarta

Arif, Dodi. (2014). Pengaruh produk domestik bruto, jumlah uang beredar, inflasi dan bi rate terhadap indeks harga saham gabungan di Indonesia 2007-2013. Jurnal Ekonomi Bisnis, 19,(3).

Atikah. (2017). Analisis pengaruh permintaan impor daging sapi di Indonesia Dari Australia Tahun 1995-2016. Skripsi. Fakultas Ekonomi. Universitas Islam Indonesia. Yogyakarta.

Boediono.(1999). Ekonomi makro. BPFE: Yogyakarta.

Boediono.(2013).Pengantar ilmu ekonomi No.1 ekonomi mikro,edisi kedua, cetakan kedua puluh delapan, BPFE, Yogyakarta.

Deliarnov.(1995). Pengantar ekonomi makro. Jakarta: Penerbit Universitas Indonesia

Emilia, E; R Nurjanah. (2015). Analisis pengaruh ekspor ke china terhadap pendapatan perkapita dan penyerapan tenaga kerja di Indonesia, Jurnal Paradigma Ekonomika $10(2)$

Fitriani, Noni. (2011). Estimasi fungsi permintaan impor tekstil Indonesia Skripsi. Fakultas Ekonomi: Universitas Jambi. 
Hastuti,D; A Delis, \& R Rosmeli. (2018). Pengembangan komoditas kelapa sawit dan karet serta dampaknya terhadap pendapatan petani di Kecamatan Pelepat Ilir, Jurnal Sains Sosio Humaniora 2 (2), 92-104

Hernadi, Doni. (2016). Analisis faktor-faktor yang mempengaruhi impor jagung Indonesia Periode 1995-2014. Skripsi. Fakultas Ekonomi. Universitas Islam Indonesia. Yogyakarta.

Insukindro. (2003). Model ekonometrika dasar. Yogyakarta: Fakultas Ekonomi UGM.

Iswandari, Diah. Ayu. (2018). Analisis faktor-faktor yang mempengaruhi impor Kedelai di Indonesia Tahun 1977-2015. Skripsi. Fakultas Ekonomi. Universitas Muhammadiyah Surakarta.

Muttoharoh,V; R Nurjanah; \& C Mustika. (2018). Daya saing dan faktor-faktor yang mempengaruhi ekspor kopi Arabika Indonesia di pasar internasional, e-Jurnal Perspektif Ekonomi dan Pembangunan Daerah 7 (3), 127-136 